\title{
FEASIBILITY ANALYSIS OF SMALL MEDIUM ENTERPRISES (MSMES) IN MANDAILING NATAL REGENCY IN ACCESSING FINANCING IN SHARIA BANK
}

\author{
Suci $^{1}$, Fatahuddin ${ }^{2}$, Sarmiana $^{3}$, Sry Lestari ${ }^{4}$ \\ ${ }^{1}$ IAIN Padangsidimpuan (Perbankan Syariah, FEBI, IAIN Padangsidimpuan) \\ ${ }^{2}$ IAIN Padangsidimpuan (Hukum Syariah, FEBI, IAIN Padangsidimpuan) \\ ${ }^{3}$ IAIN Padangsidimpuan (Perbankan Syariah, FEBI, IAIN Padangsidimpuan) \\ ${ }^{4}$ IAIN Padangsidimpuan (Perbankan Syariah, FEBI, IAIN Padangsidimpuan) \\ Elnasriwanna@gmail.com ${ }^{1}$, ikhwanuddinharahap@iain-padangsidimpuan.ac.id ${ }^{2}$, Fatahuddin@iain- \\ padangsidimpuan.ac.id ${ }^{3}$, srylestari@iain-padangsidimpuan.ac.id $^{4}$
}

\begin{abstract}
ABSTRAK
Latar belakang pada penelitian ini Usaha Mikro Kecil Menengah (UMKM) adalah usaha produktif milik orang perseorangan atau badan usaha perseorangan atau disebut juga usaha kerakyatan yang saat ini mendapat perhatian dan keistimewaan yang diamanatkan oleh undang-undang, antara lain bantuan kredit usaha dengan bunga rendah, kemudahan persyaratan izin usaha, bantuan pengembangan usaha dari lembaga pemerintah, serta beberapa kemudahan lainnya. Tidak terkecuali di Kabupaten Mandailing Natal yang rata-rata mempunyai Usaha Mikro Kecil Menengah (UMKM). Kurangnya sistem manajemen yang baik dan permodalan yang menyebabkan kegagalan Usaha Mikro Kecil Menengah (UMKM) di Kabupaten Mandailing Natal. Analisis digunakan untuk mengetahui apakah Usaha Mikro Kecil Menengah (UMKM) layak dalam mendapatkan pembiayaan dari Bank Syariah Mandiri KCP Panyabungan. Penelitian ini adalah penelitian kualitatif deskriptif. Teknik pengumpulan data pada penelitian ini adalah wawancara, observasi, dan dokumentasi. Subjek penelitian dalam penelitian ini terdiri dari First Informan yaitu pihak UMKM dan Secondary Informan yaitu pihak Bank Syari'ah Mandiri KCP Panyabungan. Hasil Penelitian dapat diketahui bahwa Pembiayaan mikro Bank Syari'ah Mandiri merupakan produk alternatif pembiayaan dari Bank Syari'ah Mandiri yang diperuntukkan bagi pengusaha UMKM (Usaha Mikro, Kecil dan Menengah). Analisis terhadap kelayakan pembiayaan mikro Bank Syari'ah Mandiri Kantor Cabang Pembantu Panyabungan terhadap calon nasabahnya adalah pengajuan harus memenuhi persyaratan: Character, Capacity, Capital, Collateral, Condition ( 5C) dan syaratsyarat yang harus dipenuhi oleh pihak UMKM. Dalam mengakses pembiayaan di bank syari'ah sangat berpengaruh disebabkan harus ada persyaratan yang mesti dilengkapi agar pencairan pembiayaan untuk Usaha Mikro Kecil Menengah (UMKM) dapat diselasaikan secepatnya dan dapat diterima oleh pihak bank.

Kata Kunci: Analisis Kelayakan, UMKM, Pembiayaan, Bank Syariah
\end{abstract}

\section{ABSTRACT}

The background of this research is Micro, Small and Medium Enterprises (MSMEs), which are productive businesses owned by individuals or private business entities, also called populist businesses, which currently receive attention and privileges mandated by law, 
including business credit assistance with low interest, ease of business permit requirements, business development assistance from government agencies, and several other facilities. No exception in Mandailing Natal Regency, which on average has a Micro, Small and Medium Enterprises (MSMEs). Lack of a good management system and capital that causes the failure of Micro, Small and Medium Enterprises (MSMEs) in Mandailing Natal Regency. The analysis is used to determine whether Micro, Small and Medium Enterprises (MSMEs) are eligible in obtaining financing from Bank Syariah Mandiri KCP Panyabungan. This research is a descriptive qualitative research. Data collection techniques in this study were interviews, observation, and documentation. The research subjects in this study consisted of First Informants namely SMEs and Secondary Informants namely Bank Mandiri Sharia Panyabungan KCP. The results of the study can be seen that the micro financing of Bank Syari'ah Mandiri is an alternative financing product from Bank Syari'ah Mandiri which is intended for MSME entrepreneurs (Micro, Small and Medium Enterprises). Analysis of the feasibility of micro financing of the Syari'ah Bank Mandiri Panyabungan Sub-Branch Office to prospective customers is that the submission must meet the requirements: Character, Capacity, Capital, Collateral, Condition (5C) and the conditions that must be met by the SMEs. In accessing financing in Islamic banks is very influential because there must be requirements that must be completed so that the disbursement of financing for Micro, Small and Medium Enterprises (MSMEs) can be resolved as soon as possible and can be accepted by the bank.

Keywords: Feasibility Analysis, MSME, Financing, Sharia Bank

\section{A. PENDAHULUAN}

Bank syari'ah merupakan salah satu bentuk dari perbankan nasional yang mendasarkan operasionalnya pada syariat (hukum) Islam. Menurut Undang-Undang No. 21 Tahun 2008 tentang Perbankan Syari'ah pasal 1, “Perbankan Syari'ah adalah segala sesuatu yang menyangkut tentang bank syari'ah dan unit usaha syari'ah, mencakup kelembagaan, kegiatan usaha, serta cara dan proses dalam melaksanakan kegiatan-kegiatan usaha, serta cara dan proses dalam melaksanakan kegiatan usahanya. (Khaerul Umam, 2013:15-16)
Bank syari'ah dalam penyediaan modal terhadap pengembangan sektor-sektor produktif berperan aktif dalam permodalan usaha mikro di Indonesia. Bank Syari'ah Mandiri salah satu bank syari'ah yang kegiatan pembiayaannya berfokus pada segmen retail dengan nama produk yaitu pembiayaan mikro. Pembiayaan mikro adalah pembiayaan bank kepada nasabah atau calon nasabah yang mempunyai usaha atau karyawan untuk kebutuhan produktif dan multiguna.

Usaha Mikro, Kecil dan Menengah diatur dalam Undang-Undang Republik Indonesia Nomor 20 Tahun 2008 tentang UMKM, 
dinyatakan bahwa usaha mikro adalah usaha

produktif milik orang perseorangan atau badan usaha perseorangan yang memiliki nilai aset paling banyak Rp. 50 juta atau dengan hasil penjualan tahunan paling besar Rp. 300 juta.( Leonardus Saiman, 2009: 4)

Analisis pembiayaan adalah kegiatan yang menelaah aspek-aspek penting dan patut diketahui dari nasabah yang akan dibiayai oleh bank. Tujuan analisis pembiayaan untuk memperoleh gambaran yang jelas dan sesungguhnya terhadap kondisi nasabah yang akan dibiayai.( Gita Danupranata, 2013:29)

Manajemen Bank Syariah akan menerima permohonan dan permintaan dari calon nasabah untuk melakukan pembiayaan setelah menganalisa permohonan dengan menggunakan prinsip 5C. Ada beberapa faktor resiko yang mempengaruhi penilaian pembiayaan yaitu sebagai berikut:

a) Character (Kepribadian atau Watak)

b) Capacity (Kemampuan atau Kesanggupan)

c) Capital (Modal atau Kekayaan)

d) Collateral (Jaminan)
POINT Vol. 2, No. 1, Jul 2021

e) Condition of Economic (Kondisi

Ekonomi)( Jopie Jusuf, 2005:195)

Berdasarkan data Data Koperasi dan UKM Kabupaten Mandailing Natal jumlah pelaku usaha yang bergerak dibidang sektor Usaha Mikro Kecil Menengah (UMKM) yang terdiri dari usaha kecil, koperasi, usaha dagang dan jenis usaha lainnya yang berjumlah $1 / 4$ dari jumlah penduduk Kabupaten Mandailing Natal yaitu 480.911 jiwa. Dengan kata lain, sistem perekonomian di Kabupaten Mandailing Natal, didominasi oleh usaha mikro kecil menengah dengan jumlah yang begitu banyak. Biasanya para pelaku Usaha Mikro Kecil dan Menengah (UMKM) di Kabupaten Mandailing Natal. Banyak mengalami kendala dalam hal permodalan dan juga masalah pemasaran produknya. 1 Berikut data UMKM yang terdapat di Kabupaten Mandailing Natal:
1 Data Dinas Koperasi Usaha Kecil dan Menengah Mandailing Natal Tahun 2019 
Tabel 1.I

Data bidang UMKM

\begin{tabular}{|c|c|c|}
\hline No. & Kecamatan & Jumlah (orang) \\
\hline 1. & Batahan & 29 \\
\hline 2. & Sinunukan & - \\
\hline 3. & Batang Natal & 578 \\
\hline 4. & Lingga Bayu & 300 \\
\hline 5. & Ranto Baek & 81 \\
\hline 6. & Kotanopan & 77 \\
\hline 7. & Ulu Pungkut & 48 \\
\hline 8. & Tambangan & 139 \\
\hline 9. & Lembah Sorik Marapi & 129 \\
\hline 10. & Puncak Sorik Marapi & 334 \\
\hline 11. & Muara Sipongi & 315 \\
\hline 12. & Pakantan & 25 \\
\hline 13. & Panyabungan & 1609 \\
\hline 14. & Panyabungan Selatan & 128 \\
\hline 15. & Panyabungan Barat & 10 \\
\hline 16. & Panyabungan Utara & 489 \\
\hline 17. & Panyabungan Timur & 9 \\
\hline 18. & Huta Bargot & 89 \\
\hline 19. & Natal & 1070 \\
\hline 20. & Muara Batang Gadis & 13 \\
\hline 21. & Siabu & 66 \\
\hline 22. & Bukit Malintang & 379 \\
\hline 23. & Naga Juang & 68 \\
\hline \multicolumn{2}{|r|}{ Jumlah } & 5985 \\
\hline
\end{tabular}

Sumber : Badan Pusat Statistik Kabupaten Mandailing Natal Tahun 2019

Berdasarkan jumlah UMKM yang terdapat di Kabupaten Mandailing Natal, jumlah UMKM terbanyak adalah di Panyabungan yang jumlahnya 1609 orang. Ini memungkinkan pelaku UMKM sendiri harus mampu bersaing untuk dapat mempertahankan usahanya.

Permasalahan lain yang sering terjadi pada Usaha Mikro Kecil dan Menengah (UMKM) perorangan yang terdapat di Kabupaten Mandailing Natal adalah tidak adanya pemisahan yang jelas antara harta usaha dengan harta pribadi untuk kepentingan konsumtif, yang akan menyebabkan berkurangnya modal usaha dan menurunkan kemampuan perputaran usaha selanjutnya.

\section{B. METODE}

Penelitian ini dilakukan pada Usaha Mikro Kecil dan Menengah (UMKM) di Kabupaten Mandailing Natal dengan sasaran para pelaku Usaha Mikro Kecil dan Menengah (UMKM) yang berlokasi di Kabupaten Mandailing Natal. Penelitian ini adalah penelitian kuantitatif, sumber data dalam penelitian ini adalah data primer data yang diperoleh secara langsung melalui Kepala Mikro Kecil Menengah BSM KCP Panyabungan yang telah memberikan pembiayaan kepada 10 Usaha Mikro Kecil dan Menengah (UMKM) sebagai subjek penelitian dan wawancara pihak pelaku Usaha Mikro Kecil dan Menengah (UMKM) dan data sekunder. teknik pengumpulan data adalah wawancara, observasi dan dokumentasi. Pengolahan data dan analisis data secara kualitatif. 


\section{HASIL DAN PEMBAHASAN}

Tingkat kelayakan mendapatkan pembiayaan dari pihak Bank Syari'ah Mandiri KCP Panyabungan harus memenuhi prosedur pembiayaan mikro, Pertama, nasabah datang ke bank untuk mengajukan permohonan pembiayaan dengan menyerahkan semua persyaratan yang dibutuhkan. Kedua bank akan melakukan analisis secara administratif (tetap) dan melakukan survei langsung ke lapangan. Ketiga, Komite pembiayaan menyusun proposal pembiayaan untuk diajukan kepada komite pembiayaan (tetap) kepala cabang. Apabila proposal pembiayaan telah disetujui oleh komite pembiayaan dan kepala cabang maka selanjutnya bank melakukan akad atau kontrak perjanjian dengan pihak nasabah.

Usaha Mikro Kecil Menengah (UMKM) di Kabupaten Mandailing Natal yang layak dalam mendapatkan pembiayaan di bank syari'ah adalah harus memenuhi persyaratan: Character, Capacity, Capital, Collateral, Condition (5C). Dalam hal ini Bank Syari'ah Mandiri Kantor Cabang Pembantu Panyabungan memiliki persyaratan yang harus dipenuhi oleh pihak Usaha Mikro Kecil Menengah (UMKM).
POINT Vol. 2, No. 1, Jul 2021

Pengaruh kelayakan Usaha Mikro Kecil Menengah (UMKM) di Kabupaten Mandailing Natal dalam mengakses pembiayaan di bank syari'ah sangat berpengaruh disebabkan harus ada persyaratan yang mesti dilengkapi agar pencairan pembiayaan untuk Usaha Mikro Kecil Menengah (UMKM) dapat diselasaikan secepatnya dan dapat diterima oleh pihak bank.

\section{PENUTUP}

\section{Kesimpulan}

Berdasarkan hasil penelitian, maka peneliti mengambil kesimpulan sebagai berikut: Tingkat kelayakan mendapatkan pembiayaan dari pihak Bank Syari'ah Mandiri KCP Panyabungan harus memenuhi prosedur pembiayaan mikro, Pertama, nasabah datang ke bank untuk mengajukan permohonan pembiayaan dengan menyerahkan semua persyaratan yang dibutuhkan.

Usaha Mikro Kecil Menengah (UMKM) di Kabupaten Mandailing Natal yang layak dalam mendapatkan pembiayaan di bank syari'ah adalah harus memenuhi persyaratan: Character, Capacity, Capital, Collateral, Condition (5C). Dalam hal ini 
Pengaruh kelayakan Usaha Mikro Kecil Menengah (UMKM) di Kabupaten Mandailing Natal dalam mengakses pembiayaan di bank syari'ah sangat berpengaruh disebabkan harus ada persyaratan yang mesti dilengkapi agar pencairan pembiayaan untuk Usaha Mikro Kecil Menengah (UMKM) dapat diselasaikan secepatnya dan dapat diterima oleh pihak bank.

\section{Saran}

Semoga adanya pengetahuan masyarakat terhadap minat produk perbankan syariah

\section{DAFTAR PUSTAKA}

Amir Machmud, Bank Syari'ah: Teori, Kebijakan, Dan Studi Empiris di Indonesia, Jakarta: Erlangga, 2010.

Ashari Akmal, Ekonomi \& Bank Syari'ah, Medan: IAIN Press, 2002.

Burhan Bungin, Metodologi Penelitian Kualitatif, Jakarta: Rajawali Pers, 2001.

Departemen Agama RI., Al-qur'an dan Terjemahannya, Jakarta: CV Diponegoro, 2005.

Dwi Suwiknyo, Kamus Ekonomi Islam, Yogyakarta: Total Media, 2009.

Ibnu Hadjar, Dasar-dasar Metodologi Penelitian, Jakarta: PT Raja Grafindo Persada, 1999.

Ismail, Perbankan Syari'ah Jakarta: Kencana, 2011.

Jopie Jusuf, Analisis Kredit Untuk Account Officer, Jakarta: PT. Gramedia Pustaka Utama, 2005.
Khaerul Umam, Manajemen Perbankan Syariah Bandung : Pustaka Setia, 2013.

Lexy J.Moleong, Metode Penelitian Kualitatif, Bandung: PT. Remaja Rosdakarya, 2000.

Muhammad, Bank Syari'ah, Yogyakarta: Graha IImu, 2005.

Manajemen Dana Bank Syariah,

Jakarta: Rajawali, 2014.

Nasroen Yasabari, \& Nina Kurnia Dewi, Penjaminan Kredit: Mengantar UKMK Mengakses Pembiayaan, Bandung: PT. ALUMNI, 2014.

Rachnawan Budiarto, Pengembangan UMKM: Antara Konseptual dan Pengalaman Praktis, Yogyakarta: Gajah Mada University Press, 2015.

Sugiyono, Metode Penelitian Bisnis, Bandung: Alfabeta, 2012.

, Metode Penelitian Pendidikan: Pendekatan Kuantitatif, Kualitatif, dan R\&D, Bandung: Alfabeta, 2012.

Suharsimi Arikunto, Prosedur Penelitian: Suatu Pendekatan Praktik, Jakarta: PT. Rineka Cipta, 2006.

Trisadini P. Usanti \& Abd. Shomad, Transaksi Bank Syari'ah, Jakarta: PT Bumi Aksara, 2015.

Undang-Undang Republik Indonesia Nomor 20 Tahun 2008 Tentang Usaha Mikro, Kecil, dan Menengah.

Veithzal Rivai, \& Andria Permata Veithzal, Islamic Financial Management, Jakarta: Raja Grafindo Persada, 2008.

Zainul Arifin, Memahami Bank Syari'ah, Jakarta: Alvabet, 2000. 